\title{
COMPOSITES MADE WITH NATURAL FIBERS AND POLYMERS, REVIEW AND BENNEFITS
}

\author{
Fabio Ferreira Bomfim ${ }^{a}$, Josiane Dantas Viana ${ }^{b}$ \\ a, Senai Cimatec, Brazil, \\ b, Instituto de Tecnologias da Saúde - Materials, Senai Cimatec, Brazil
}

\begin{abstract}
This study aims to make a review on natural fibers characteristics, polymers and composites, exemplifying those benefits to use renewable materials into polymers and showing how the application of specifics amounts of percentage of natural fibers into polymers help the environmental sustainability, improving mechanical properties of the material. Further research will be conducted to create a new composite between polymer and piassava natural fiber.
\end{abstract}

Keywords: Composites; Natural fibers; Polymers; Engineering Materials

\section{COMPÓSITOS CONSTITUÍDOS COM FIBRAS NATURAIS E POLÍMEROS, REVISÃO E BENEFÍCIOS}

Resumo: Este estudo tem como objetivo fazer uma revisão sobre características, polímeros e compósitos de fibras naturais, exemplificando os benefícios do uso de materiais renováveis em polímeros e mostrando como a aplicação de quantidades específicas de porcentagem de fibras naturais em polímeros ajuda a sustentabilidade ambiental, melhorando as propriedades mecânicas do polímero. Mais pesquisas serão conduzidas para criar um novo composto entre polímero e fibra natural de piassava.

Palavras-chave: Compósitos; Fibras naturais; Polímeros; Engenharia de Materiais 


\section{INTRODUCTION}

Nowadays Brazil is the $4^{\text {th }}$ highest plastic waste producer on the world, and recycle only $1 \%$ of the total amount produced [1]. Based on that the utilization of natural fibers with polymers is a good choice in terms of sustainability, incentive of environment preservation, ecology, light weight and renewable materials [2].

Natural fibers are a definition for fibers that are not manmade, synthetic or from any kind of industrial process. They are generally being found on plants or animals [3]. Each one of the natural fibers has a different characteristics and properties, and dozens of natural fibers types was discovered and used for diverse applications. Natural fibers generally consist on his composition: Cellulose, Hemicellulose, Lignin, Pectin and waxy substances [4].

The average amount of $\mathrm{CO} 2$ that can be removed from an entire forest with one acre of extension in South America on the first 20 years of life is approximately 26 tons per year, after this growing-up tree period, the number goes 7.6 tons of $\mathrm{CO} 2$ removed from the forest per year [5]. This information ensure that produces natural fibers helps the environmental conservation and bring many benefit to the society and nature.

Natural Fibers Polymeric Composites can be known as a material made with a polymer and a natural fiber. Many researchers are studying those materials and his potential opportunity on incorporate in many applications. Generally, the application of natural fibers in polymers reduce the amount of petrol based resources on the material, reduce the overall weight of the parts, increase their mechanical properties, increase flexibility and also help to reduce cost, because most of the natural fibers are very cheap and easily found on nature [6].

Piassava is one kind of natural fibers. Brazil has a productive area for piassava plantation with an average size of $32 \mathrm{~K}$ acre, the amount of piassava produced in Brazil is about 57 tons per year [7]. Bahia state is the Top \#1 producer of piassava fiber in Brazil, their production represents $90 \%$ of the total amount of piassava produced in Brazil. One arroba of piassava has already been commercialized by $R \$ 140,00$ on the past, nowadays is negotiated by $\mathrm{R} \$ 30,00$, one arroba has approximately $15 \mathrm{Kg}$. An estimative says that Bahia has more 2 million acres ready to be used for piassava plantation, that may further increase Bahia's production capacity [8].

Piassava is obtained from a specific kind of Palmeira tree that is called Attalea Funifera, the fiber is found on the trunk tree and can be easily removed without harvest the entire tree, just the fiber is taken off. One Attalea Funifera tree can produce $10 \mathrm{Kg}$ of Piassava fiber per year [8].

\section{METHODOLOGY}

Based on a systematic review, the synthetic fibers are generally produced with good manufacturing controls and under tolerance process, that's contributes to a fiber very organized in terms of range of properties and homogeneous microstructural aspects, details will be showed in Figure 1 [9]. 
Figure 2. SEM view of synthetic fibers: (a) glass, (b) carbon, and (c) aramid
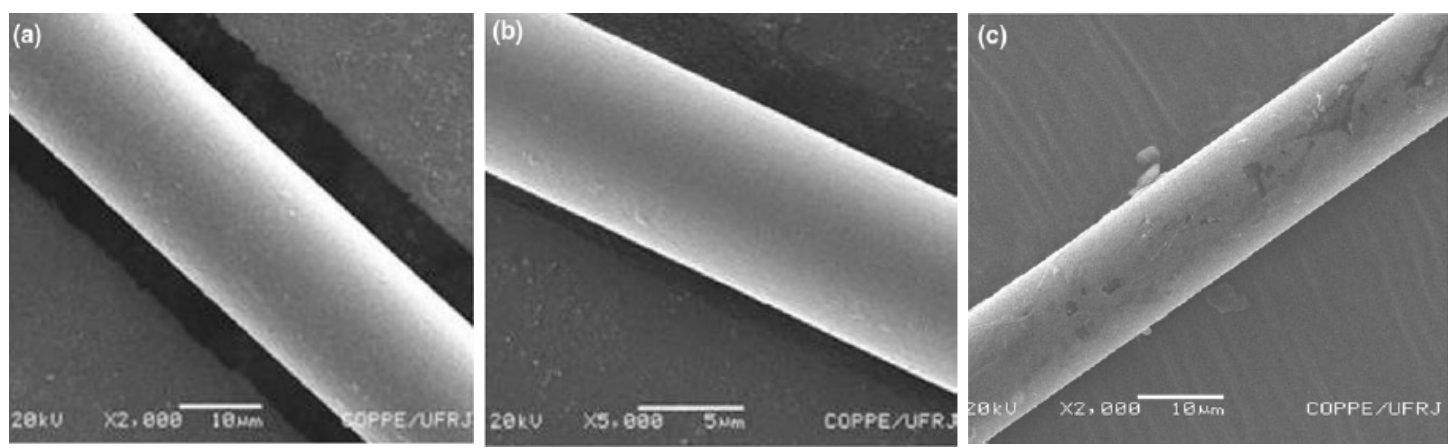

In the other hand, when we talk about the Natural Fibers, they can be generally characterized by unequal range of properties and heterogeneous microstructural aspects, these aspects will be identified on Figure 2 [9]. As the Natural Fibers is produced on the nature, is very hard to found some natural fibers without defects, because the production varies in many aspects over the year, depending on the weather condition, quality of the plant location and age of the plant.

Figure 2. SEM view of natural lignocellulosic fibers: (a) sisal, (b) bamboo, (c) coir, and (d) piassava
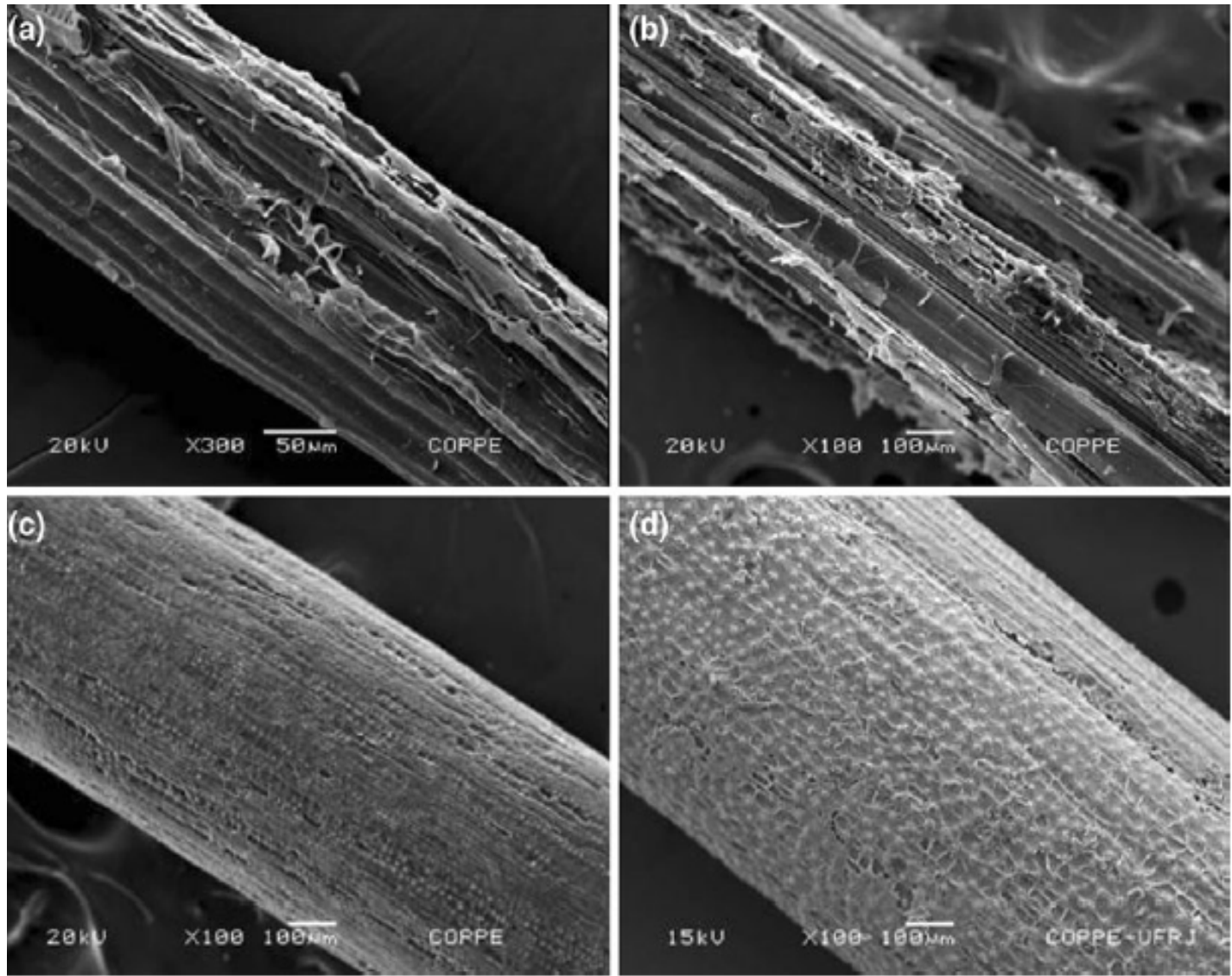
Natural fiber polymer composite generally permits moisture absorption from the environment, that usually cause weakness in terms of adhesion and bindings between the fiber and the polymer. The binding between natural fiber and polymer are considered a big challenge because the internal and chemical structure of both materials are very different. Generally, when we found a composite with low mechanical properties, one of the reasons is the ineffectual stress transfer during the adhesion between the fiber and polymer on the production of the composite [4].

Specifics treatments on the natural fiber are certainly necessary to improve adhesion between the fiber and the polymer, they are generally centered on the utilization of reagent functional groups which can change the fiber structure and composition, resulting in a natural fiber that support more moisture absorption, leading to a better enhancement incompatibility between the fiber and polymer matrix [10].

The lower density of all natural fibers is a major advantage for possible uses on composites with polymers. This combination is used on automotive application as reinforcement of lighter components. Low weight and low density is a key property of many natural fibers, that combined with high strength, bending module and flexural stiffness result in efficient composites [11]. Below we can see a Table 1 showing many natural fibers and those related Densities and Tensile Strength values.

Table 1. Natural Fibers X Density, Tensile Strength and Young's Modulus

\begin{tabular}{|c|c|c|c|}
\hline & $\begin{array}{l}\text { Density } \\
\left(\mathbf{g} / \mathrm{cm}^{3}\right)\end{array}$ & $\begin{array}{l}\text { Tensile Strenght } \\
\text { (MPa) }\end{array}$ & $\begin{array}{c}\text { Young's Modulus } \\
\text { (GPa) }\end{array}$ \\
\hline $\begin{array}{l}\text { Piassava } \\
\text { (Attalea } \\
\text { funifera) }\end{array}$ & 1.10 to 1.45 & 109 to 1750 & 5 to 6 \\
\hline $\begin{array}{l}\text { Sisal } \\
\text { (Agave } \\
\text { Sisalana) }\end{array}$ & 1.26 to 1.50 & 287 to 913 & 9 to 28 \\
\hline $\begin{array}{l}\text { Bamboo } \\
\text { (Bambusa } \\
\text { Vulgaris) }\end{array}$ & 1.03 to 1.21 & 106 to 204 & - \\
\hline $\begin{array}{l}\text { Banana } \\
\text { (Musa } \\
\text { Sapientum) }\end{array}$ & 0.67 to 1.50 & 700 to 800 & 27 to 32 \\
\hline $\begin{array}{l}\text { Coir } \\
\text { (Cocos } \\
\text { nucifera) }\end{array}$ & 1.15 to 1.52 & 95 to 220 & 4 to 6 \\
\hline $\begin{array}{l}\text { Jute } \\
\text { (Corchorus } \\
\text { capsularis) }\end{array}$ & 1.30 to 1.45 & 393 to 800 & 13 to 27 \\
\hline
\end{tabular}


Natural fibers composites essentially show good strength (MPa) with low density compared to many other classic materials, characterizing as a key on the improvements of new materials for such diverse applications. Natural fibers are represented on the chart with similar strength (MPa) as engineering alloys and with minimum weight design, due to low density values. Due to impressive characteristics the Natural Fibers composites is recognized as a new class of material, in a great position [9]. Below we can see the Figure 3 showing a comparable chart details related to Strength $(\mathrm{MPa})$ and Density $\left(\mathrm{Mg} / \mathrm{m}^{3}\right)$.

Figure 3. Renewable composites made with Natural Fibers in a Strength-density chart

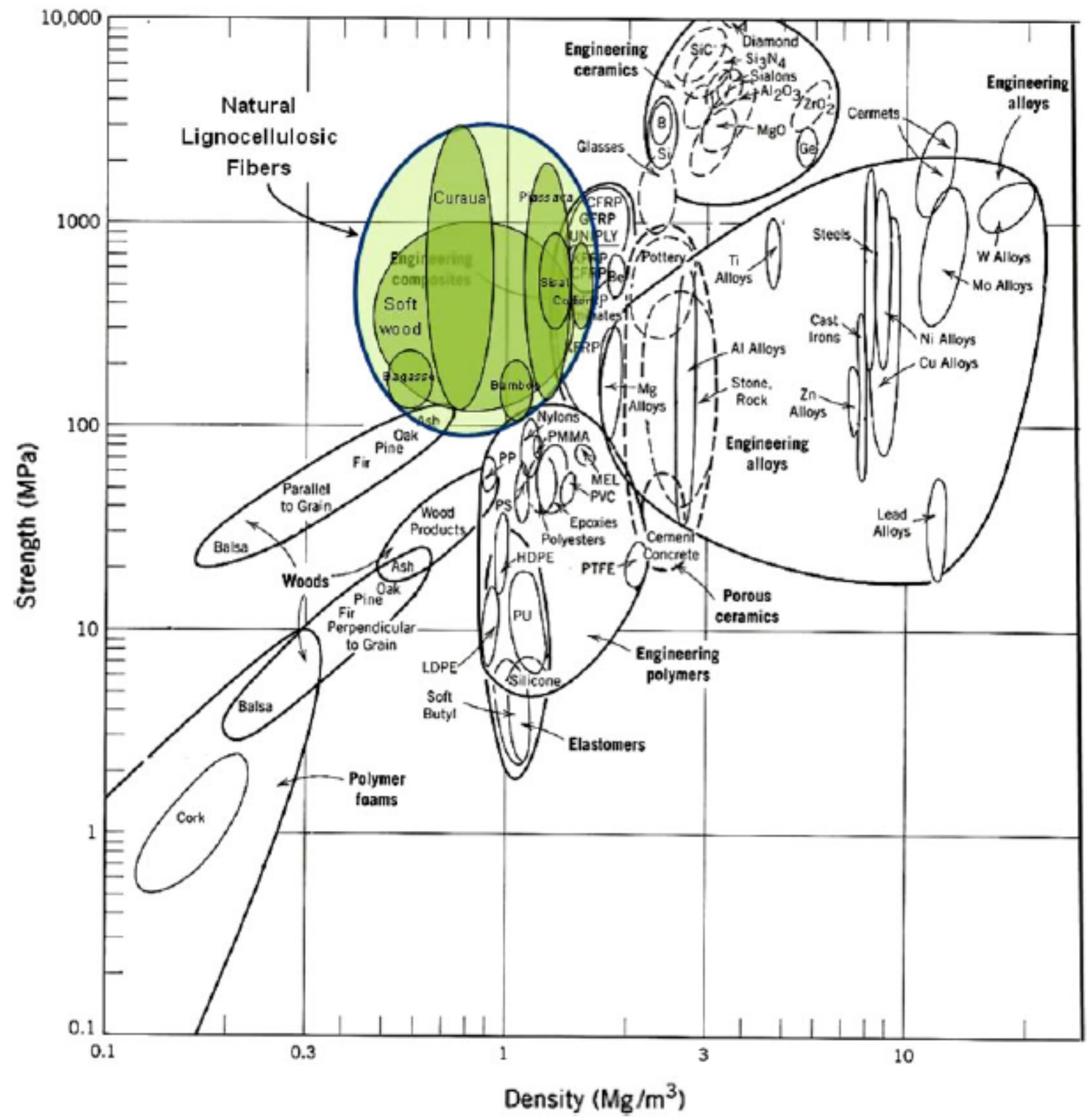




\section{RESULTS AND DISCUSSION}

Results indicated that the application of natural fibers with polymers is to produce high quality engineering materials with a percentage of renewable resources and bio-degradable materials, contributing to the maintenance of environmental conservation and reducing pollution.

Brazil can play in a great position on usage of renewable resources and raw material on plastics composites, due to a very important agriculture and mass production of many grains, oils and huge plantation areas. The challenge is to develop even more projects on the field related to increase the utilization of those kind of materials, producing high efficient and quality renewable plastic compounds, helping the environment to become eco-friendlier.

Nowadays natural fibers composites have a huge room of utilization improvement all over the world, and on the Brazilian market is not different, those renewable materials can be applied on automotive, reinforcing of polymeric matrices, structural components, packaging, food-services, consumer electronics, consumer goods and household appliances. The utilization of those materials must be a \#1 priority in order to help the environment to reduce the carbon foot print. The future perspectives are to speed up production of those renewable materials to gain more ecologically benefits.

The further challenge of this study on the future is to apply renewable plastic compound made by polypropylene and piassava on automotive plastic parts, such as door modulus, door trim panel, and interior console. The Senai Cimatec Materials Lab facilities will be a big partner to enhance and open the possibilities to make diverse composites with different percentage amounts of piassava and test those characteristics as density, tensile strength, flexion test, impact resistance and analysis on SEM - Scanning Electron Microscope.

\section{CONCLUSION}

On this basis, the utilization of natural fibers in addition with petrol based polymers resulting in another material classification commonly known as composites. The composites development is a big challenge for the production of high quality materials, with good mechanical properties and percentage of bio-renewable resources on his composition. All this characteristic together combines in an important field of study into Engineering Material Science and Engineering Materials. 


\section{REFERENCES}

${ }^{1}$ COELHO, Tatiana. Brasil é o $4^{\circ}$ maior produtor de lixo plástico do mundo e recicla apenas 1\%: País produz 11 milhões de toneladas de lixo plástico por ano. In: Brasil é o $4^{\circ}$ maior produtor de lixo plástico do mundo e recicla apenas $1 \%$ : País produz 11 milhões de toneladas de lixo plástico por ano. Brasil: G1 Globo, 4 mar. 2019. Disponível em: 04/03/2019. Acesso em: 8 jul. 2019.

2ELZUBAIR, Amal; C.M.C. Bonelli; Morphological, structural, thermal and mechanical characterization of piassava fibers. J Natural Fibers 2007;4(2):13-31

${ }^{3}$ UDDIN, N et al. Developments in fiber-reinforced polymer (FRP) composites for civil engineering: 13. Thermoplastic composites for bridge structures. 13. ed. Birmingham: University Of Alabama, 2013

${ }^{4}$ MOHAMMED, Layth; ANSARI, M. N. M.; PUA, Grace; JAWAID, Mohammad; ISLAM, M. Saiful. A Review on Natural Fiber Reinforced Polymer Composite and Its Applications. International Journal Of Polymer Science, Malaysia, p. 1-16, ago. 2015.

${ }^{5}$ HERNDANDEZ, Manoela. Qual é o valor de uma árvore?: O sequestro de carbono. Sebrae: ECYCLE, Brasil, p.2-4, 21 set. 2016.

${ }^{6} \mathrm{KU}, \mathrm{H}$; WANG, H; PATTARACHAIYAKOOP, N; TRADA, M. A review on the tensile properties of natural fiber reinforced polymer composites. Composites Part B: Engineering, Australia, v. 42, n. 4, p. 856-873, Jun. 2011.

${ }^{7}$ GT 2 GARGALOS DAS CULTURAS DO SISAL, MALVA, PIAÇAVA,COCO, SEDA E BAMBU: BREVE PANORAMA PARA ORIENTAR UMA PROPOSTA DE GOVERNANÇA. Salvador: Câmara Setoriais de Fibras Naturais Csfn / Mapa, 20 mar. 2019.

8 GUIMARÃES, Carlos Alex Lima; SILVA, Luiz Alberto Mattos. Piaçava da Bahia: Do extrativismo à cultura agrícola. Ilhéus: Editus - Editora UESC, 2012. 264 $\mathrm{p}$

${ }^{9}$ MONTEIRO, Sergio Neves; LOPES, Felipe Perisse' Duarte; BARBOSA, Anderson Paula; BEVITORI, Alice Barreto; SILVA, Isabela Leão Amaral da; COSTA, Lucas Lopes da. Natural Lignocellulosic Fibers as Engineering Materials-An Overview. Metallurgical And Materials Transactions A, Rio de Janeiro, v. 42, n. 29, p. 2963-2974, jul. 2011. 
10 RAY, Ss; BOUSMINA, M. Biodegradable polymers and their layered silicate nanocomposites: in greening the 21st century materials world. Progress In Materials Science, Sainte-foy, v. 50, n. 1, p. 962-1079, maio 2005.

${ }^{11}$ MARSH, George Perkins. Man and Nature. Washington: University Of Washington, 2003 